\section{SEVENTY YEARS AGO}

NATURE, vol. 2, May I9, I870

\section{Scientific Education}

The leading article, under this title, discusses the facilities for training in the sciences available in Great Britain, with special reference to the Royal Commission recently appointed to consider Government aid to science. Referring to the Science and Art Department, it has been questioned whether this scheme has fulfilled the purpose for which it was originated. While the advantages of the scheme have been great, in that it is under the direction of men of the highest eminence, it is contended that the scheme operates mainly for the benefit of the technical schools founded by Government, and thereby forces an official plan of education upon the country. "To such we would remark, that the quantity of Science taught is so small, that it is not wise to attempt in any way to reduce that quantity; but it is certainly to be wished that the Commission should carefully inquire whether this method is one calculated to extend a sound Science education over the whole country".

A plea is made for consideration of the claims of such independent institutions as University College, London, King's College, London, and Owens College, Manchester.

\section{Intellect and Size of Brain}

According to the British Medical Journal, the weight of the late Sir James Simpson's brain, including the cerebellum, was 54 ounces. While, as is well known, the ratio between intellect and size of brain is by no means close, yet there can be no doubt that it is very important. Most of our great men have had large crania. The male brain ranges between 46 and 53 ounces, its average being $49 \frac{1}{2}$ (Quain and Sharpy). That of Cuvier is stated to have weighed 64 ounces, and that of the late Dr. Abercrombie 63 ounces, but it is possible that some error may have crept in through the use of weights of different standards. If not, Sir James's brain, whilst much above the average, did not nearly reach those of the celebrated men we have mentioned; but at the same time, the convolutions were remarkably numerous; they were, says a correspondent, "twisting and turning round on each other as if they could not find room within the head. The island of Reil was very wonderful"'.

AN interesting application of photography to legal evidence has just taken place. The Spanish Government having refused to give up the Tornado, an English vessel captured some time since, or to give compensation to the owners, our own Government has acquiesced in the decision, a photographic copy of the private instructions given to the captain by the owners having proved conclusively the more than doubtful character of the vessel.

CorResPondence on the "Strange Noises heard at Sea off Grey Town" continues. Charles Kingsley relates his own experiences and suggests that Drum fish (Pogomias) are responsible; Staff Capt. F. J. Evans, F.R.S., also quotes his own experiences and suggests "musical fish or shells"; H. P. Mallet suggests the presence of gas-bubbles rising from a mud containing much vegetable matter.

\section{FORTHCOMING EVENTS}

[Meetings marked with an asterisk are open to the public.]

Monday, May 20

Royal Geographical Socitix, at 5 p.m.--Prof. O. T. Jones, F.R.S. : "Oceanic Shelves".

\section{Tuesday, May $2 \mathrm{I}$}

Chadwick Lecture (at the London School of Hygiene and Tropical Medicine, Keppel Street, W.C.1), at 2.30 p.m.-Prof. S. P. Bedson, F.R.S. : "Human Virus Infections of Animal Origin, their Mode of Spread and Control".*

Royal Institution, at 5.15 p.m.-Dr. L. H. Lampitt : "The Manufacture, Preservation and Distribution of Food".*

\section{Thursday, May 23}

Society of Chemical Industry (Chemroal EngineerING GRoUP) (at the Waldorf Hotel, Aldwych, W.C.2), at 6.45 p.m.- Twenty-first Annual General Meeting.

Friday, May 24

Royal Astronomical Societry, at 4.30 p.m.-Discussion on "River Flow". (Opening paper by Capt. W. N. MeClean.)

Association of Special Lmbrartes and Information BURfaux (in the Lecture Hall of the Science Museum, South Kensington, S.W.7), at 5 p.m.-Discussion to be opened by Dr. L. Newcombe on "The Accessibility of Thesis Literature". Discussion by Dr. J. N. Goldsmith on "Errata and Corrigenda".

Royal Institution, at 9 p.m.-Prof. L. C. Martin : "Ultra-Violet and Electron Microscopy".

\section{Saturday, May 25}

British Psychological Society (at 55 Russell Square, W.C.I), at 3 p.m.--H. W. Durant : "A Critical Account of Public Opinion Measurement".

At 5.30 p.m.-J. G. W. Davies: "Individual Differences between Psychological Workers".

At 6.15 p.m.-Alec Rodger and Patrick Slater : Report on "Some New Non-verbal Tests".

\section{APPOINTMENTS VACANT}

APPLICATIONS are invited for the following appointments on or before the dates mentioned:

Assistant Lecturer IN Mathematics-The Principal, Science Department, Technical College, Kingston-upon-Thames (May 21). HEADMIsraEss of the County School for Girls, Gravesend-Mr. W. A. Clench, Bank Chambers, Windmill Street, Gravesend (May 25). Lecturar in Plant Pathology and Zoologx-The Principal, LECTURER IN PLANT PATHOLOGY AND ZOOLOG - The
Horticultural College for Women, Swanley, Kent (May 31).

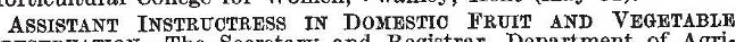
PRESERVATION-The Secretary and Registrar, Department of Agriculture and Horticulture (University of Bristol), Long Ashton (May 31). PRINCIPAL of St. Mary's College (for Women) (University of Durham) The Secretary, Durham Colleges' Office, 38 North Bailey, Durham (May 31).

AdMinistrative Assistant--The Director of Education, Lindsey ADMINISTRATIVE AssistaNT--The Director of Educe
Education Office, County Offices, Lincoln (June 1).

HeApMaster OF WELLINGBOROUGH COLLEGE-The Clerk to the Governors, 1 High Street, Wellingborough (June 1).

LECTURERS (two) IN CIVIL AND MECHaNICAL ENGINEERING subjects, and a LECTURER IN ELECTRICAL ENGINFERING subjects-The Sectetary, Northampton Polytechnic, St. John Street, F.C.1 (June 10).

LEOTURER IN BOTANY at the University of Cape Town-The LECTURER IN BOTANY at the University of Cape Town- The Secretary, Office of the High Commissioner
Africa, Trafalgar Square, W.C.2 (June 29).

TEACHer of PHYsics at the Rugby College of Technology and Arts-The Principal and Organizer of Further Education in Rugby 61 Clifton Road, Rugby.

DIRECTOR of EDdCATION-The Town Clerk, Town Hall, Salford 3. ENGINeER for the Malayan Postal Service--The Crown Agents for the Colonies, 4 Millbank, S.W.1 (quoting M/9113).

Charge Enaineer for the Flectrical Department of the Federated Malay States-The Crown Agents for the Colonies, 4 Millbank, S.W.1 (quoting M/9018). 